\title{
Contribution to non-Apis bee fauna of family Apidae (Hymenoptera) from Layyah, Punjab, Pakistan
}

\author{
Muhammad Adnan Bodlah¹, Yasir Niaz ${ }^{1}$, Muhammad Tariq Rasheed², Ammara Gull e Fareen², \\ Muhammad Nawaz ${ }^{1}$, Kamran Ikram¹, Muhammad Mohsin Waqas ${ }^{1}$, Bilal Rasool ${ }^{3}$, Imran Bodlah ${ }^{2 *}$ \\ ${ }^{1}$ Fareed Biodiversity Conservation Centre, Department of Agricultural Engineering, Khawaja Fareed University of \\ Engineering and Information Technology, Rahim Yar Khan, Punjab, Pakistan \\ ${ }^{2}$ Insect Biodiversity and Conservation Group, Department of Entomology, PMAS-Arid Agriculture University, Rawalpindi, \\ Pakistan \\ ${ }^{3}$ Department of Zoology, Faculty of Life Sciences, Government College University, Faisalabad
}

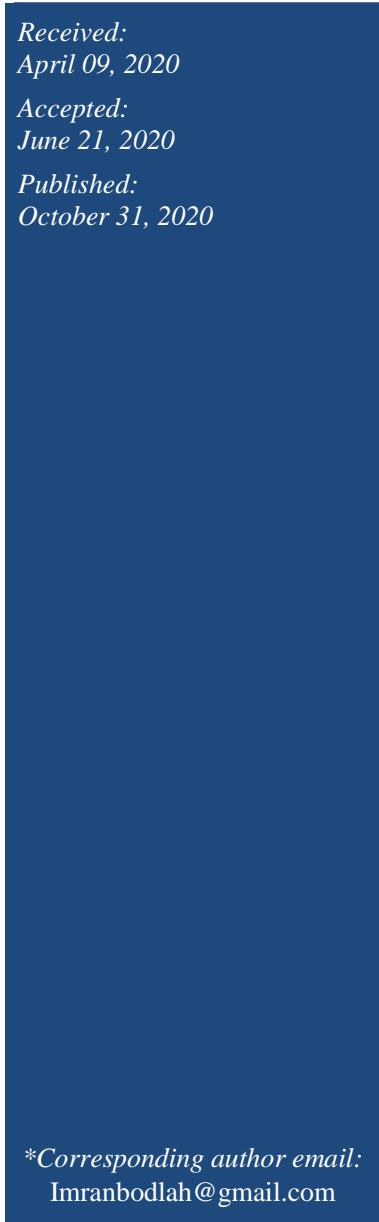

\section{Abstract}

Global decline in Apis bee population has shifted research towards the exploration of Non-Apis bees. A lot of work has been done on the role of Non-Apis bees in pollination services, stability of ecosystem and their synergistic effects on pollination of Apis bee. These aspects have not yet been studied regarding the local Non-Apis bees fauna of Pakistan due to lack of basic research on these bees. Layyah being the multi crop area was selected as study area for the exploration of these bees. Current research work was aimed to explore the Non-Apis bee fauna of district Layyah. Surveys were carried out from different localities during 2017-18. Bee's specimens were collected by net sweeping methods, brought to the laboratory and identified up to species level by following standard protocols of identification. Macrophotography of identified species was done using high magnification power microscope attached with a camera. Herein eleven Non-Apis bee species are recorded for the first time from various localities of district Layyah. Present baseline research work will be helpful in future to manage bee's population and uplifting of the bee pollination for the better crop yields in the current surveyed areas of the Punjab province of the Pakistan. Results of this research may be used to study the role of these bees on foraging behaviors, pollination efficiency and ecosystem stability by local Apis bee. Individual role of all these bees regarding the pollination of various crops, fruits vegetables may be further explored in the region.

Keywords: Non Apis, Bees, Apidae, Layyah, Punjab, Pakistan

\section{How to cite this:}

Bodlah MA, Niaz Y, Rasheed MT, Fareen AGE, Nawaz M, Ikram K, Waqas MM, Rasool B and Bodlah I, 2020. Contribution to non-Apis bee fauna of family Apidae (Hymenoptera) from Layyah, Punjab, Pakistan. Asian J. Agric. Biol. 8(4): 428-435. DOI: https://doi.org/10.35495/ajab.2020.04.227

This is an Open Access article distributed under the terms of the Creative Commons Attribution 3.0 License. (https://creativecommons.org/licenses/by/3.0), which permits unrestricted use, distribution, and reproduction in any medium, provided the original work is properly cited.

\section{Introduction}

The current bee fauna inheres back to cretaceous times when the plants were established and bees found to be linked with the flowering plants. Bee value as an agent for plant reproduction in cross pollination is inestimable (Michener, 2000). The domesticated crops are pollinated by bees directly or they are included in 
varieties of horticultural bee cross pollinated plants. Bee-pollinated trees, wild flowers, bushes are needed to be conserved to prevent the soil erosion problem which is essential for food provision and as a cover for wildlife. Similarly, the bee conservation in wild is also important to improve the genetic diversity needed in the cultivated strains (Michener, 2007). Bees are major ecological service providers particularly in crosspollination. All over the world, pollinator's issues for the pollination have been raised for the maintenance of the natural and agricultural ecosystem. Management of agriculture is widely dependent on bee pollination (Ingram et al., 1996). About 20,000 species of bees have been described in the world. Some of them are carpenter bees, leaf cutting bees, sweat bees and mason bees (Ascher and Pickering, 2014; Michener, 1965). They are the major part of insect order hymenoptera and belong to the aculeate hymenopterans group of families under superfamily Apoidea including Apidae, Colletidae, Andrenidae, Halictidae, Stenotritidae, Melittidae and Megachilidae (Michener, 2000). Other than genus Apis, bees are named as wild, pollen or Non-Apis bees (Aslam et al., 2017).

Non-Apis bees have become more important for pollination because of drastic decline in Apis bees populations availability due to the attack of tracheal and Varroa mites. The devastation of Apis cerana Fabricius colonies was observed due to the spread of Thai Sac brood virus (Rajagopal and Kencharaddi, 2000). Eventually an outrageous decrease in bee population resulted in deprived plants from pollination. Alternatively, wild or Non-Apis bees should be given more attention to fulfill the proper pollination requirements as these bees can play a better role in the pollination of specific plant species those are not visited by Apis bees efficiently. Under many conditions, these bees are a better choice for pollination because of their buzz pollination, fast foraging, longer tongue length, efficient tripping and oligoleptic foraging (Nayana, 2008).

About 5700 bee species have been reported under the family Apidae. According to the recent classification, all genera previously classified in families Ctenoplectridae and Anthophoridae families, have now been included in three subfamilies of family Apidae including Xylocopinae, Nomadinae and Apinae (Michener, 2007). The honey bees, bumble bees, stingless bees and orchid bees are included in Apidae. Whereas, cuckoo bees and carpenter bees belong to Nomadinae and Xylocopinae (Danforth et al., 2013). The family Apidae bee species are social and solitary. This family also includes cleptoparastic species (O'Toole and Anthony, 1991).

There have been few attempts towards the assessment of bee diversity, conservation and their documentation in Pakistan. In fact, the knowledge about the bee genera or species in Pakistan is scanty. Even regional faunal lists are few and limited in number (Fiaz, 1977; O'Toole and Anthony, 1991; Suhail et al., 2009; Maryam, 2012; Sheikh et al., 2015; Iqbal, 2016). Layyah is the district present in southern part of the Punjab province of Pakistan (30-45 to 31-24 o N and 70-44 to 71-50 o E). It comprises three tehsils including Karor Lal-Esan, Chaubara and Layyah. Tehsil Choubara consists of sand dunes and forests and almost barren. The district Layyah is agriculturally well developed but vastly covered with the tracks of sand dunes. Layyah district thus have a preferred and attractive land for Non-Apis bee life and activities. With all keeping in view the present study was designed with the objectives to explore different species of Non-Apis bees occurring in district Layyah. These bee records will be helpful in their conservation, sustainability, for the better pollination of the crops not properly visited by Apis bee species.

\section{Material and Methods}

During the current surveys, collection of specimens was only confined to the non-Apis bee (Wild, pollen or non- bee pollinators) fauna of the district Layyah. For this purpose, two Tehsils (Karor Lal Esan \& Layyah) were surveyed (Fig.1). The main crops of the district are wheat, chickpea, cotton, sugarcane, and fodders like lucern, barseem and sorgum. Bitter gourds, squashes are the vegetables while mangoes, guava, beri and citrus are grown as the fruiting plants. The weather conditions of the district Layyah vary from too cold in winter ranging from $2^{\circ} \mathrm{C}$ degree in January and highest temperature $45^{\circ} \mathrm{C}$ in June. Similarly, the average rainfall of the district is about 18.7 centimeters during monsoon season months JulyAugust (Lok Sanjh Foundation, 2013). A total of 342 bee specimens were studied and the details of methodology followed during the course of these investigations are given here.

\section{Bee collection, identification and preservation}

The bees were collected from different host plants including crops, weeds, and ornamentals by aerial net sweeping. The specimens were killed in a glass jar 
containing potassium cyanide. All collected specimens were tagged and mounted using common pins. Kruss microscope was used for the identification. Bees were identified to the species level by using the available identification keys (Popov, 1967; Bingham, 1897; Michener, 2007). However, if needed, help was also taken from the already published research about non-bee fauns of Pakistan (Bodlah et al., 2016a, b). The identified species were photographed with the help of Labomed CZM6 microscope (10X / 22 W.F). The body measurements of specimens were taken in $\mathrm{mm}$ and abbreviated as body length (BL), forewing length (FL) and forewing width (FW). All the research work was carried out in the insect taxonomy laboratory and identified specimens were deposited in the insect museum of Fareed Biodiversity and Conservation Centre (FBCC), Department of Agricultural Engineering, Khwaja Fareed University of Engineering and Information Technology, Rahim Yar Khan, Punjab, Pakistan for future studies.

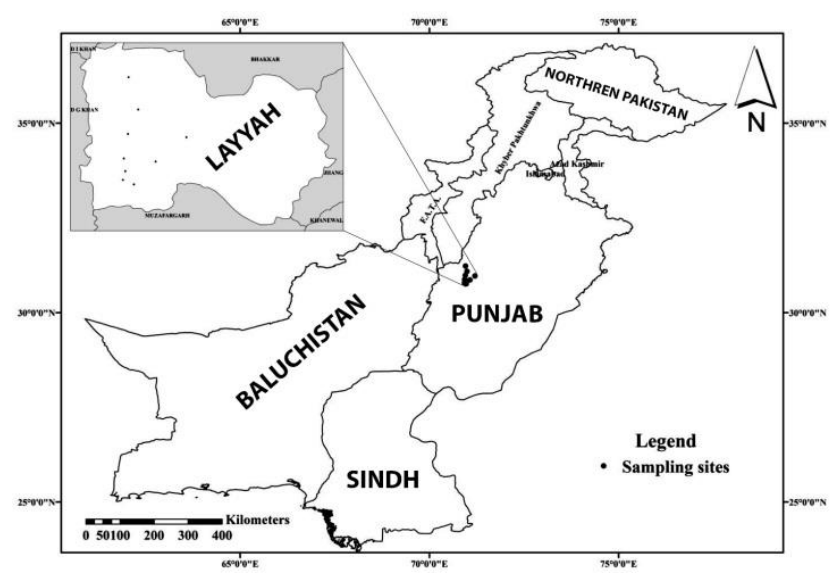

Figure-1. Distribution map of collected bees' specimens from Layyah district of Punjab, Pakistan

\section{Results}

As a result of this research, total 11 species namely; Amegilla (Zonamegilla) cingulata (Fabricius, 1775), Anthophora confusa (Smith, 1854), Thyreus himalayensis (Radoszkowski, 1893), Thyreus ramosus (Lepeletier, 1841), Nomia (Nomia) crassipes (Fabricius, 1798), Nomia (Nomia) curvipes (Fabricius, 1793), Nomia (Hoplonomia) elliotii (Smith, 1875), Nomia (Hoplonomia) westwoodii (Gribodo, 1894), Xylocopa (Koptortosoma) pubescens (Spinola, 1838), Xylocopa (Ctenoxylocopa) fenestrata (Fabricius, 1798), Ceratina (Pithitis) smaragdula (Fabricius,
1787) have been explored for the first time from Layyah. These were collected from various host plants including crops, ornamental plants, flowers etc.

Amegilla (Zonamegilla) cingulata (Fabricius, 1775) Fig: 2A

\section{Material examined}

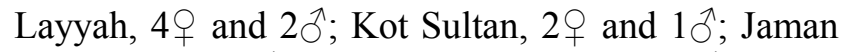
Shah, $2 q$ and 3 ${ }^{\lambda}$; Karor Lal Esan, $4 \uparrow$ and $2 \hat{\jmath}$.

\section{Floral host plants}

Cynodon dactylon, Eruca sativa and Chrysanthemum Sp.

\section{Measurements}

BL 9.5-10 mm; FL 7.5 mm; FW 3-4 mm (Male) BL 11-11.5 mm; FL 8-9 mm; FW 4.5-5 mm (Female)

\section{Comments}

Amegilla (Zonamegilla) cingulata (Fabricius, 1775) is worldwide in distribution and reported from countries like Australia, Burma, Sri Lanka, India (Gupta, 2003); Korea, Northeast China, Indonesia and Yemen (Michener, 2007). This species has already been reported on various host plants from Pothowar region of Pakistan by Bodlah et al. (2016a). Now it is recorded for the first time from Layyah district (Southern Punjab) area of Pakistan. Moreover, the specimens collected from Layyah were found to be similar with the previous studies of Michener (2007) and Bodlah et al. (2016a).

\section{Anthophora confusa (Smith, 1854) Fig: 2B Material examined}

Layyah, 69 and 3 $\delta^{\lambda}$; Chowk Azam, 19 and 1 $\delta^{\lambda}$; Jaman Shah, $2 q$ and $1 \delta^{\lambda}$; Karor Lal Esan, $5 q$ and $3 \hat{\delta}$.

\section{Floral host plants}

Brassica campestris and Eruca sativa

\section{Measurements}

BL 9.5 mm; FL 6.5-7 mm; FW 3.5-4.5 mm (Male)

BL 10-11.5 mm; FL 7.5-8 mm; FW 4-5 mm (Female)

\section{Comments}

Anthophora confusa (Smith, 1854) is distributed in various countries like Burma, India, Southeast Asia and African regions (Bingham, 1897; Michener, 2007). This species has already been described by Bodlah et al. (2016a). The collected bees were 
compared with the previous descriptions given by Bodlah et al. (2016a) and were found similar. This species is reported first time from Layyah.

\section{Thyreus himalayensis (Radoszkowski, 1893) Fig:} 2C

Materials examined

Layyah, 19 and 4 ${ }^{\wedge}$; Chowk Azam, 29 and $5 \hat{\circ}$; Jaman Shah, $1+$ and $7 \hat{\gamma}$; Kot Sultan, $1+$ and $4{ }^{\lambda}$; Ladhana, $1 ㅇ$ and $3{ }^{\lambda}$.

\section{Floral host plants}

Premna foetida and Brassica campestris

\section{Measurements}

BL 9 mm; FL 6.5 mm; FW 3.5 mm (Male)

BL 9-10 mm; FL; 6.5-7 mm; FW 4 mm (Female)

\section{Comments}

This species is already recorded from various countries of the world like South Africa, Sri Lanka, India, China, Philippines, Southeast Asia and Pakistan (Bingham, 1897; Michener, 2007). Identified specimens of this species were compared with previous studies by Michener (2007) and Bodlah et al. (2016a) and found to be similar.

Thyreus ramosus (Lepeletier, 1841) Fig: 2D Material examined

Layyah, $7 \uparrow$ and 3 $\delta^{\lambda}$; Chowk Azam, $6 q$ and $2 \hat{\jmath}$

Floral host plants

Ocimum basilicum, Bidens Sp. and ornamental plants.

\section{Measurements}

BL 9-11 mm; FL 8.5.9 mm; FW 3.5-4 mm (Male)

BL 10 mm; FL 7-7.5 mm; FW 3-4 mm (Female)

\section{Comments}

This species is reported from Thailand, Vietnam, Taiwan, Nepal, China, Pakistan (Williams et al., 2010; An et al., 2011), Egypt, South Africa and Europe (Bingham, 1897; Michener, 2007). This bee species is reported for first time from Southern Punjab (Layyah).

\section{Nomia (Nomia) crassipes (Fabricius, 1798) Fig: 2E} Material examined

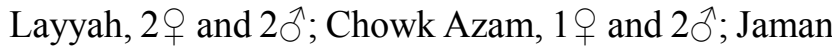
Shah, $2+$ and $3{ }^{\lambda}$; Kot Sultan, $3 q$ and $2{ }^{\lambda}$; Kazmi Chowk, $2 q$ and $6{ }^{\lambda}$

\section{Floral host plants}

Silybum marianum, Phaseolus vulgaris and Carthamus oxycanthus

\section{Measurements}

BL 11-12mm; FL 8-9mm; FW 3-4 mm (Male)

BL 9-11 mm; FL 6.5-7 mm; FW 3.5-4 mm (Female)

\section{Comments}

Nomia (Nomia) crassipes is distributed in different countries like India, Thailand, China, Africa and Pakistan (Michener, 2007). The specimens collected during present study were found similar when compared with the already published literature by Bingham (2005) and Pauly (2009). These bees are reported for the first time from Southern Punjab (Layyah).

Nomia (Nomia) curvipes (Fabricius, 1793) Fig: 2F Material examined

Layyah, $1 q$ and $0{ }^{\lambda}$; Pir Jagi Shareef, $2 q$ and $4{ }^{\lambda}$; Kot

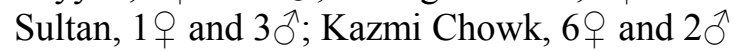

Floral host plants

Phaseolus vulgaris and Carthamus oxycanthus

\section{Measurements}

BL 10-11 mm; FL; 7.5-8 mm; FW 2.5-3 mm (Male)

BL 11 mm; FL; 6 mm; FW 3 mm (Female)

\section{Comments}

This species is already reported from India, Indonesia, Burma and Pakistan (Bingham, 1897). Moreover, the collected bee specimens during current study were found similar when compared with the already published bee fauna by Michener (2007) and Pauly (2009). This species was recorded from Pothowar region of Pakistan by Bodlah et al. (2016b) and now reported for the first time from Southern Punjab (District Layyah).

Nomia (Hoplonomia) elliotii (Smith, 1875) Fig: 2G Material examined

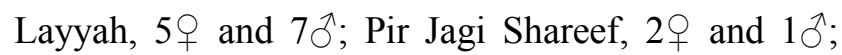
Chowk Azam, 6 q and $3{ }^{\widehat{T}}$;

\section{Floral host plants}

The host range of this specie includes different weeds, crop plants and ornamentals. Bees have been found nesting in the soil. 


\section{Measurements}

BL 10-11 mm; FL 7.5-8 mm; FW 2.5-3 mm (Male)

BL $11 \mathrm{~mm}$; FL; 6 mm; FW 3 mm (Female)

\section{Comments}

This species is reported from Philippines, China, Australia, Indonesia, Japan, India and Pakistan (Michener, 2007). All the collected bee species specimens were compared with the description given by Pauly (2009) and Bodlah et al. (2016b). The reported species is already been published from Pothowar region of Pakistan by Bodlah et al. (2016b). Now it is reported for the first time from Southern Punjab.

Nomia (Hoplonomia) westwoodii (Gribodo, 1894) Fig: $2 \mathbf{H}$

\section{Material examined}

Layyah, $5 q$ and 7 $\hat{\delta}$; Pir Jagi Shareef, $2 q$ and $1 \hat{\jmath}$; Chowk Azam, 59 and $5 \hat{\jmath}$.

\section{Floral host plants}

The host range of this species includes unknown weeds and some ornamental plants.

\section{Measurements}

BL 8.5-9 mm; FL; 6-7 mm; FW 2.5 mm (Male)

BL 10.5 mm; FL; 6.5-7 mm; FW 3.5-4 mm (Female)

\section{Comments}

Nomia (Hoplonomia) westwoodii is recorded from various countries of the world like Southeast Asian countries, India and Pakistan (Michener, 2007). The collected specimens were compared with the already published bee fauna by Bingham (2005) and Pauly (2009) and were found similar. These bees are reported for the first time from Layyah.

\section{Xylocopa (Koptortosoma) pubescens (Spinola, 1838)} Fig: 2I

Material examined

Layyah, $3 \uparrow$ and $4 \hat{\jmath}$; Chowk Azam, $4 \uparrow$ and $5 \hat{\jmath}$;

\section{Floral host plants}

Phaseolus vulgaris and Jacaranda mimosifolia

\section{Measurements}

BL 23-26 mm; FL; 16-17 mm; FW 8-9 mm (Male)

BL 24-28 mm; FL 17-19 mm; FW 7-8 mm (Female)

\section{Comments}

Xylocopa (Koptortosoma) pubescens has been reported from the countries like Africa, Egypt, Philippines, India, Japan, Indonesia and Australia (Bingham, 1897; Michener, 2007). The collected specimens were compared with description given by Bodlah et al. (2015) and were found similar. These non Apis bees are reported for the first time from Layyah.

Xylocopa (Ctenoxylocopa) fenestrata (Fabricius, 1798) Fig: 2J

Material examined

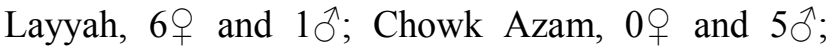
Hafizabad, $3 \circ$ and $7 \hat{0}$

\section{Floral host plants}

Alstonia scholaris, Jacaranda mimosifolia, Punica granatum and Brassica campestris

\section{Measurements}

BL 25-29 mm; FL 18-20 mm; FW 7-9 mm (Male) BL 27-30 mm; FL; 16-18 mm; FW 8 mm (Female)

\section{Comments}

This species has been reported from India, Burma (Bingham, 1897), South Africa, Israel, Russia, Iraq, India and Pakistan (Michener, 2007). The collected specimens were compared with studies by Bodlah et al. (2015) and Aslam et al. (2017) and found similar. These bees are reported for the first time from district Layyah. 


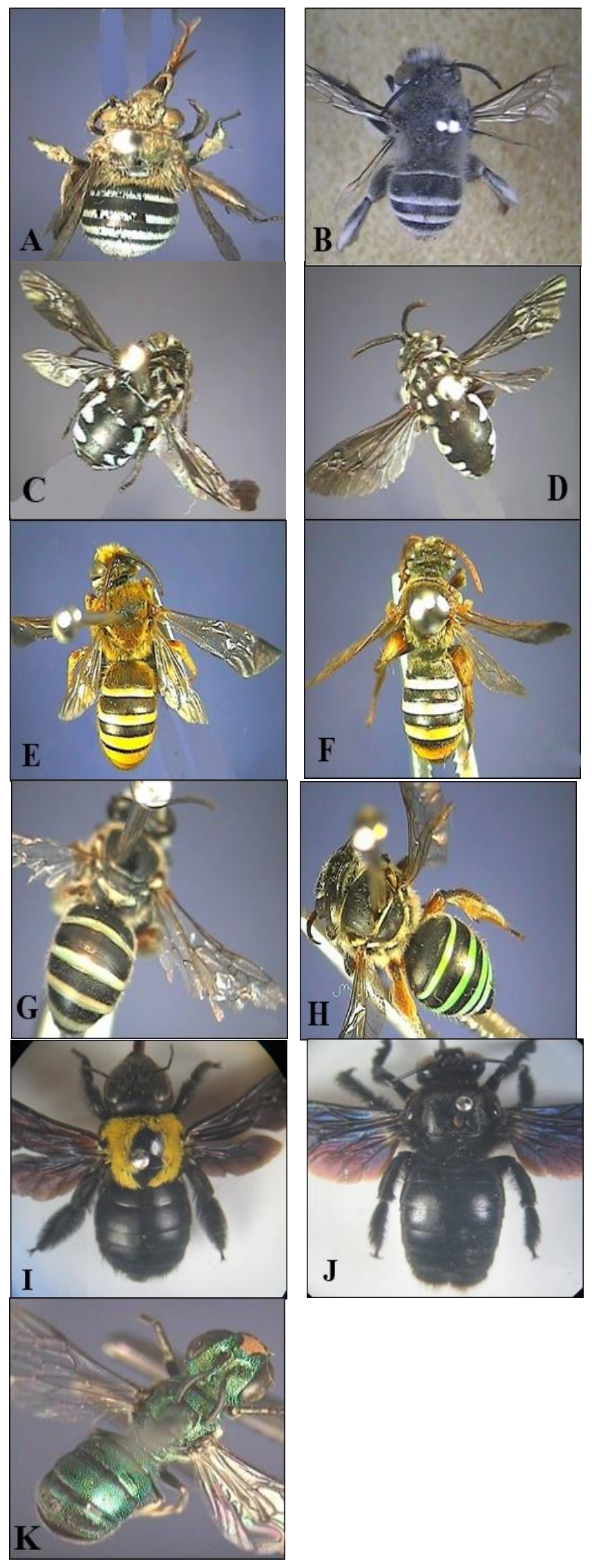

Fig.2. Amegilla (Zonamegilla) cingulata (A), Anthophora confusa (B), Thyreus himalayensis (C), Thyreus ramosus (D), Nomia (Nomia) crassipes (E), Nomia (Nomia) curvipes (F), Nomia (Hoplonomia) elliotii (G), Nomia (Hoplonomia) westwoodii (H), Xylocopa (Koptortosoma) pubescens (I), Xylocopa (Ctenoxylocopa) fenestrata (J), Ceratina (Pithitis) smaragdula (K)

Ceratina (Pithitis) smaragdula (Fabricius, 1787) Fig: 2K

Material examined

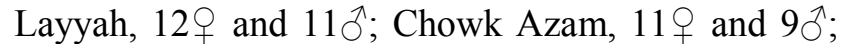
Hafizabad, $4+$ and 5 $\overbrace{}^{\lambda}$; Kot Sultan, $3 q$ and $6 \AA$.

\section{Floral host plants}

Calotropis procera, Abelmoschus esculentus and Ocimum basilicum

\section{Measurements}

BL 6-7 mm; FL 3-4 mm; FW 2-3 mm (Male)

BL 6-7 mm; FL 4 mm; FW 3 mm (Female)

\section{Comments}

This species is already reported from the countries like Yemen, Egypt, Senegal, South Africa, Saudi Arabia, Sri Lanka, India, Philippines, China, Indonesia, Taiwan and Pakistan (Michener, 2007). All the observed specimens were compared with published description by Bodlah et al. (2015) and found similar. These bees are also reported for the first time from district Layyah.

\section{Discussion}

During current study, overall 11 species belonging to 6 genera from different host plants were recorded from various localities of district Layyah. Bodlah et al. (2015) reported three species with their floral host plants from the four district of Pothwar region of Pakistan. Similarly Bodlah et al. (2016 a, b) reported eight species from different localities of Pothwar region. Aslam et al. (2017) reported 10 species from Chakwal, Jhelum, Attock, Rawalpindi and Islamabad. According to some studies, non-Apis bees were found more efficient than honey bees in flower tripping, nectar and pollen collection visits (Cane, 2002). Generally more than $80 \%$ of the wild bees have the ground nesting behavior and are not managed for the crop pollination (Cane, 2003). Their sustainability 
requires nesting sites, avoidance of land without vegetation and judicious use of insecticides (Johansen and Mayer, 1990). Moreover, their survival, crop visitation and pollination are also under danger due to some predacious problems (Mayer and Johansen, 1978).

\section{Conclusion}

The non-Apis bees recorded in present study will be supporting for the conservation, sustainably and uplifting of the crops yields in southern Punjab tract of Pakistan in future. More extensive studies in Southern Punjab are needed for the exploration of non-Apis bee Fauna of this region.

\section{Acknowledgement}

The authors of this manuscript would like to thank $\mathrm{Mr}$. Muhammad Amjad for providing literature and supporting in specimens confirmation.

\section{Disclaimer: None.}

Conflict of Interest: None.

Source of Funding: None.

\section{References}

An J, Williams PH, Zhou B, Miao Z and Qi W, 2011. The bumblebees of Gansu, Northwest China (Hymenoptera, Apidae). Zootaxa. 2865: 1-36.

Ascher SJ and Pickering J, 2014. Discover Life Bee species guide and world checklist (Hymenoptera: Apoidea: Anthophila) [Internet]. Discover Life. Ceylon and Burma. Vol-1. Taylor and Francis, London. 579p.

Aslam S, Rafi MA and Zia A, 2017. Non-Apis bees of family Apidae (Hymenoptera) from Pothwar region of Pakistan. J. Entomol. Zool. Stud. 5: 612.

Bingham CT, 1897. The Fauna of British India, Including Ceylon and Burma. Hymenoptera-Vol. 1. Wasps and Bees. Taylor and Francis, London. 447-450.

Bingham CT, 2005. The fauna of British India including Ceylon and Burma, Hymenoptera, Wasps and Bees. Taylor and Eastern Entomologist. 154:1-16

Bodlah I, Amjad M, Ahmad M, Gulzar A, Aziz MA, Bodlah MA and Naeem M, 2015. Two Genera of
Xylocopinae (Hymenoptera) with floral host plants from Pothwar (Punjab) Pakistan. Pak. Entomol. 37: 33-37.

Bodlah I, Amjad M, Bodlah MA and Qayyum A, 2016a. First record of two genera of Anthophorini and one genus of Melectini (Apinae: Apidae: Hymenoptera) from Pothwar Punjab, Pakistan. J. Entomol. Zool. Stud. 4:1031-1035

Bodlah I, Amjad M, Bodlah MA and Saeed M, 2016b. Record of Sweet Bees, Genus Nomia Latreille, 1804 (Halictidae: Apoidea) from Pothwar tract, Pakistan. J. Entomol. Zool. Stud. 4: 178-182.

Cane JH, 2002. Pollinating bees (Hymenoptera: Apiformes) of US alfalfa compared for rates of pod and seed set. J. Econ. Entomol. 95: 22-27.

Cane JH, 2003. Exotic non-social bees (Hymenoptera: Apoidea) in North America: Ecological implications. For non-native crops, whence pollinators of the future. pp. 113-126.

Danforth BN, Cardinal S, Praz C, Almeida EA and Michez D, 2013. The impact of molecular data on our understanding of bee phylogeny and evolution. Annu. Rev. Entomol. 58: 57-78.

Fiaz M, 1977. Role of insects in the pollination of Sunflower. M.Sc Thesis Department of Entomology, University of Agriculture, Faisalabad, Punjab, Pakistan.

Gupta RK, 2003. An annotated catalogue of bees of the Indian Region. An E Book. Accessed from: https://www.oocities.org/beesind2/ on 15 June 2020.

Ingram M, Nabhan, GP and Buchmann SL, 1996. Ten essential reasons to protect the birds and the bees (No. F/582.01662 I5).

Iqbal Z, 2016. Species composition of bees (hymenoptera) Pollinating almond plantation in district Ghizer Gilgit Baltistan. M. Phil thesis, Department of Plant and environmental protection PARC Institute of Advance study in Agriculture, NARC, Islamabad, Pakistan.

Johansen CA and Mayer DF, 1990. Pollinator protection: A bee and pesticide handbook, Wicwas Press, Cheshire, Connecticut.

Lok Sanjh Foundation, 2013. Thal Desert: A Research Study on Understanding Desert Ecology and Livelihood Patterns. Accessed from: http://loksanjh.org/wpcontent/uploads/pdf/Desert_Ecology_Study.pdf

Maryam H, 2012. Insect pollinator fauna of apricot from Gilgit Baltistan. M. Phil Thesis. PARC Institute of Advance Studies in Agriculture 
(PAIASA), Islamabad, Pakistan.

Mayer DF and Johansen CA, 1978. Bionomics of Meloe niger Kirby (Coleoptera: Meloidae) a predator of the alkali bee, Nomia melanderi Cockerell (Hymenoptera; Halictidae). Melanderia. 28: 1-22.

Michener C, 2000. The Bees of the World. The Johns Hopkins University Press, Baltimore, Maryland, USA.

Michener CD, 1965. A classification of the bees of the Australian and South pacific regions. Bull. Am. Museum Nat. Hist. 130:1-362.

Michener CD, 2007. The Bees of the World, 2nd Edition. The Johns Hopkins University Press, Baltimore, Maryland, USA.

Nayana ED, 2008. Studies on Non-Apis bee faunal diversity of western ghat region of Karnataka. M.Sc. Thesis. The University of Agricultural Sciences, Bangalore, India.

O'Toole C and Anthony R, 1991. Bees of the world. The Johns Hopkins University Press. Baltimore, Maryland, USA.

Pauly A, 2009. Classification des Nomiinae de la Région Orientale, de Nouvelle Guinée et des îles de 1'Océan Pacifique (Hymenoptera: Apoidea: Halictidae). Entomologie. 79: 151-229.

Popov VV, 1967. Bees (Hymenoptera, Apoidea) of Central Asia and their distribution on flowering plants. Trudy Zoologicheskogo Instituta, Akademia Nauk SSSR [Transactions of the Zoological Institute, Academy of Sciences USSR]. 38: 11-329.

Rajagopal D and Kencharaddi RN, 2000. Thai sac brood virus disease of Indian honey bee.
Department of Apiculture UAS, Bangalore, India. Sheikh UAA, Ahmad M, Aziz MA, Naeem M, Bodlah I and Imran M, 2015. First record of genus Bombus Latreille (Hymenoptera: Apidae, Bombini) in Naran Kaghan valley of Pakistan and their floral host range. J. Biol. Environ. Sci. 7: 215-223.

Suhail A, Sabir AM, Asghar M, Rafi MA and Qadir A, 2009. Geographic distributional patterns of the genus Bombus (Bombini: Apidae: Hymenoptera) in northern Pakistan. Biol. Divers. Conserv. 2: 19.

Williams PH, Ito M, Matsumura T and Kudo I, 2010. The bumblebees of the Nepal Himalaya (Hymenoptera: Apidae). Insecta Matsumurana. New series: J. Faculty Agric. Hokkaido Univ., Series Entomol. 66: 115-151.

\section{Contribution of Authors}

Bodlah MA: Collected the samples and wrote the paper

Niaz Y: Provided research guideline

Rasheed MT: Species mapping and identification Fareen AGE: Species mapping and identification Nawaz M: Provided research guideline Ikram K: Proofread the article Waqas MM: reviewed the article Rasool B: Species photography Bodlah I: Species identification and helped in writing paper 